\title{
Population Dynamic of Tetranychus urticae and Euseius scutalis on some Plants in Organic Farming in Egypt
}

\author{
Shahira M. EL-Bishlawy*; Sally, F. Allam*; A. S. Hassan*and B. A. Soudy ** \\ ${ }^{*}$ Dept. of Zoology and Agric. Nematology. Fac. of Agric., Cairo Univ. Giza. Lgypt. \\ ${ }^{* *}$ Applied Center of Entomol. Nematodes. Fac. of Agric., Cairo Univ. Giza, Egypt.
}

\begin{abstract}
This study was conducted for one year from September 2014 to determine the population dynamics of Tetranychus urticae and Euseius scutalis (A.-H.) on omamental, medicinal and aromatic plants (Hibiscus sabdarriffa L.., Mentha vridis L., Mentha. piperita L. and Syngonium podophyllum Schott) at Giza and Qualyubia govemorates. A positive correlation occurred between population densities of both mites and weather factors. T. urticae population on Mentha vridis L., Hibiscus sabdarriffa L., Mentha. piperita L. and Syngoniumpodophyllum Schott increased to reach population on Nov. $1^{\text {st }}$

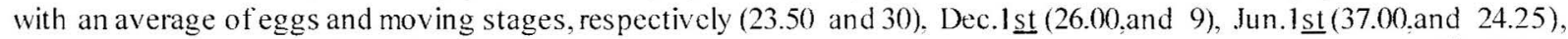
Sept.1st (37.00 and 24.25) and Euseius scutalis on May $1^{\text {st }}$ (15.25and 24.75), Dec. $1^{\text {st }}$ (25and 22.25), Dec.15 $5^{\text {th }}$ (26.00 and 42.25). Then the lowest level of population on Sept.1 $5^{\text {th }}$ (3.25 and 12.5), Apr. $1^{\text {st }}\left(9.50\right.$ and 6), Sept. $1^{\text {st }}(2015)$, (11.50 and 18.5), Mar. $1^{\text {st }}\left(8.50\right.$ and 12.75) and Euseius scutalis Sept.15 $5^{\text {th }}$ (3.25 and 3.75), Sept. $1^{\text {st }}(9.50$ and 14.75), Jan. $1^{\text {st }}(9.50$ and 15.55$)$, Mar. $1^{\text {st }}(9.25$ and 13.25$)$ in this data showed that population of T. urticae and E. scutalis increased to high value in Nov. and Dec. and decreased in numbers on Mar. and Apr. cause of this require to removing weeds in time after this menthes and plants condition.
\end{abstract}

Key words: Ornamental; Aromatic; Medicinal plants; Hibiscus sabdarriffa L.; Mentha vridis L.; Mentha piperita L. ; Syngonium podophyllum Schott; Tetranychus urticae Koch; Euseius scutalis (A.-H.).

\section{INTRODUCTION}

Aromatic and medicinal plants are important sources of herbs and spices which are a good natural source for the synthesis of more complicated flavors, fragrances, pharmaceuticals, vitamins and other important chemicals. Different types of insect and mites are infesting it.

Previous studies have shown that $E$. scutalis is one of the predators of the spider mite T. urticae, and immatures of whiteflies (Swirski et al., 1967).

The present study was conducted to determine the population dynamics of Tetranychus urticae and associated E. scutalis on leaves of the ornamental, medicinal and aromatic plants (Hibiscus sabdarriffa, M. vridis, M. piperita and Syngonium podophyllum Schott at Giza and Qualyubia governorates for one year. This may throw lights to reduce using pesticides in organic farming.

\section{MATERIALS AND METHODS}

This study was conducted for one year from September 2014. Samples were collected from two locations (Research of Prerogative of Medicinal and Aromatic Plants center at Gezerat El-Shieer, El-Qanatir El-Khiriya, Qualyubia governorate and the Faculty of Agriculture Cairo university farm in Giza).

Random samples each of 27 leaves from the three ornamental and aromatic plants (Hibiscus sabdarriffa L., Mentha vridis L., M. piperita L. and Syngonium podophyllum Schott) and debris of associated ground were taken throughout the growing season. Mites were extracted by modified Tullgren funnel and identified to species level. Weather records were taken from Meteorological Station of agricultural Res. Cent. Dokki, Giza.

\section{RESULTS AND DISCUSSION}

Population dynamics of E. scutalis and associated T. urticae on leaves of the ornamental, medicinal and aromatic plants Hibiscus sabdarriffa, Mentha vridis, M. piperita and Syngonium podophyllum, for one year, were given in Tables $1 \& 2$.

Data determined that $T$. urticae population increased gradually to reach its peak on Nov. $1^{\text {st }}$ with averages 23.50 and 30 per nine leaves, respectively; then it gradually decreased to reach the lowest level at mid September for moving stages and eggs with averages of 3.25 and 12.5 per nine leaves, respectively. The intercourse between the population of adults, moving stages and eggs of E. scutalis and daily mean temperature was significantly positive for all stages, the amounts of L.S.D values were in Jan. 15 13.00 and 6.75 then population gradually increased to reach the peak on Maylst 15.25 and 14.75 per nine leaves, respectively. The population then gradually decreased to reach the lowest level at September for moving stages and eggs with averages of 3.25 and 3.75 pei nine leaves, respectively. 
Table 1: Population dynamic of T. urticae on H. sabdarriffa, M. vridis, M. piperita and S. podophyllum for one year from September 2014 at Qualyubia and Giza governorates

\begin{tabular}{|c|c|c|c|c|c|c|c|c|c|c|}
\hline \multirow{2}{*}{$\begin{array}{c}\text { Sampling } \\
\text { date }\end{array}$} & \multicolumn{2}{|r|}{ M. vridis } & \multicolumn{2}{|c|}{ II. sabdarriffa } & \multicolumn{2}{|c|}{ S. podophyllum } & \multicolumn{2}{|c|}{ M. piperita } & \multirow{2}{*}{ Tmp. } & \multirow{2}{*}{ R.H.\% } \\
\hline & eggs & moving stages & eggs & moving stages & eggs & moving stages & eggs & moving stages & & \\
\hline Sept. & 13.1 & 20.5 & 23.3 & 41.9 & 65 & 44.6 & 26 & 44.5 & 45 & 57 \\
\hline Oct. & 35.5 & 38.3 & 24.8 & 18.9 & 38.1 & 52.8 & 33.8 & 43 & 27 & 58.5 \\
\hline Nov. & 48 & 71.5 & 26.8 & 11.1 & 39 & 49.8 & 39.5 & 31 & 25 & 62 \\
\hline Dec. & 36.5 & 46.5 & 44.5 & 21.2 & 35 & 37 & 50.5 & 41 & 19 & 48.5 \\
\hline Jan. & 20.3 & 22.8 & 31 & 12.6 & 43.3 & 62.1 & 61 & 38.6 & 15.5 & 55.5 \\
\hline Feb. & 21.3 & 16.5 & 23.6 & 11.5 & 44 & 37.3 & 44 & 30.5 & 18 & 48 \\
\hline Mar. & 34.3 & 13.3 & 30.1 & 17.1 & 21 & 49.8 & 32.6 & 33.5 & 26.5 & 48 \\
\hline Apr. & 46.3 & 37.5 & 28 & 18.1 & 34.3 & 37.5 & $\overline{34.6}$ & 36.3 & 28 & 61.5 \\
\hline May & 65 & 62.8 & 33.6 & 24.1 & 46.3 & 62.8 & 46.3 & 62.8 & 36.5 & 48 \\
\hline Jun. & 38.5 & 44.6 & 36.8 & 24.9 & 65 & 44.6 & 65 & 44.6 & 42.5 & 36 \\
\hline Jul. & 54.5 & 27.3 & 29.8 & 29.6 & 38.5 & 27.3 & 38.5 & 27.3 & 39 & 52 \\
\hline Aug. & 23 & 29.3 & 19 & 35.4 & 52.8 & 35 & 54.5 & 29.3 & 36.5 & 54.5 \\
\hline Sept. & 23.5 & 11.5 & 19 & 45.3 & 36.3 & 25.5 & 23.5 & 11.5 & 36.5 & 51 \\
\hline $\mathrm{LSD}_{5 \%}$ & 7.4 & 7.4 & 7 & 14.5 & 8.9 & 13.7 & 9.5 & 11.3 & & \\
\hline
\end{tabular}

Table 2: Population dynamic of E. scutalis on H. sabdarriffa, M. vridis, M. piperita and S. podophyllum for one year from September 2014 at Qualyubia and Giza governorates

\begin{tabular}{|c|c|c|c|c|c|c|c|c|c|c|}
\hline \multirow{2}{*}{$\begin{array}{c}\text { Sampling } \\
\text { date }\end{array}$} & \multicolumn{2}{|r|}{ M. vridis } & \multicolumn{2}{|c|}{ H. sabdarriffa } & \multicolumn{2}{|c|}{ S. podophyllum } & \multicolumn{2}{|c|}{ M. piperita } & \multirow{2}{*}{ Tmp. } & \multirow{2}{*}{ R.H.\% } \\
\hline & $\operatorname{cgg} s$ & moving stages & eggs & moving stages & $\operatorname{eggs}$ & moving stages & eggs & moving stages & & \\
\hline Sept. & 6.6 & 6.6 & 22.5 & 49.3 & 24.8 & 43.9 & 43.5 & 65.8 & 45 & 57 \\
\hline Oct. & 24 & 24 & 23 & 39.1 & 27.8 & 42.5 & 30.8 & 54.3 & 27 & 58.5 \\
\hline Nov. & 30.8 & 30.8 & 23.6 & 35.5 & 26.3 & 45.8 & 41 & 69.8 & 25 & 62 \\
\hline$\overline{\text { Dec. }}$ & 22.6 & 22.6 & 37.5 & 33.1 & 31.5 & 54.5 & 38.8 & 62.6 & 19 & 48.5 \\
\hline Jan. & 29.5 & 29.5 & 30.5 & 46.3 & 26.5 & 42.5 & 25.5 & 32.9 & 15.5 & 55.5 \\
\hline Feb. & 25.3 & 25.3 & 21.8 & 32.5 & 27 & 49.8 & 27.3 & 49 & 18 & 48 \\
\hline Mar. & 25.1 & 25.1 & 26.3 & 35.8 & 25.1 & 36.3 & 22.3 & 28 & 26.5 & 48 \\
\hline$\Lambda \mathrm{pr}$. & 28.3 & 28.3 & 29.8 & 40.8 & 28.3 & 54.6 & 24.6 & 48.4 & 28 & 61.5 \\
\hline May & 29.3 & 29.3 & 24.3 & 29.1 & 29.3 & 46.3 & 26.3 & 42.2 & 36.5 & 48 \\
\hline Jun. & 28.8 & 28.8 & 24.1 & 39.3 & 28.8 & 44.8 & 22.8 & 41.5 & 42.5 & 36 \\
\hline Jul. & 26 & 26 & 31.8 & 29.1 & 26 & 46 & 23.6 & 45.5 & 39 & 52 \\
\hline Aug. & 29.8 & 29.8 & 31.8 & 42.9 & 30 & 52.8 & 25.6 & 56.1 & 36.5 & 54.5 \\
\hline Sept. & 13 & 13 & 9.5 & 14.5 & 15.5 & 16 & 10.3 & 19.5 & 36.5 & 51 \\
\hline $\mathrm{LSD}_{5 \%}$ & 3.7 & 3.7 & 5.2 & 12.2 & 4.3 & 7.6 & 5.8 & 12 & & \\
\hline
\end{tabular}

Population dynamics of T. urticae and E. scutalis on $\boldsymbol{H}$. sabdarriffa.

Obtained results are parallel with that of Shereef et al. (1981) who studied the population densities of the phytophagous mites T. urticae and its predatory mites on peppermint in Giza, Egypt, during (1978). Data showed that the first appearance of T. urticae $\mathbf{P}$ occurred on Sept. - for moving stages and eggs, respectively. Population then gradually increased to reach its the peak on Dec. ${ }^{1 \text { st }}$ with averages (26.00 and 9) per nine leaves, respectively. The population then gradually decreased to reach the lowest level on $\mathrm{Apr}^{\text {lit }}$ for both moving stages and eggs with averages 12.5 and 3.00 per nine leaves, respectively.

The intercourse between the population of moving stages and eggs of E. scutalis and daily mean temperature was significantly positive for all stages; amounts of L.S.D values were in Jan. 13.00 and 6.75, population gradually increased to reach the peak on
Dec. with averages 25 and 11.75 per nine leaves, respectively; then the population gradually decreased to reach the lowest level onSept. ${ }^{\text {th }}$ for moving stages and eggs with averages of 9.50 and 14.45per nine leaves, respectively.

\section{opulation dynamic of T. urticae and E. scutalis on M. piperita.}

Data determined that the population gradually increased to reach the peak for T. urticae on Jun. with averages 37.00 and 24.25 per nine leaves, respectively; then the population gradually decreased to reach the lowest level at Sept.2015 for moving stages and eggs with averages of 11.50 and 18.5 per nine leaves, respectively The intercourse between the population of adults, moving stages and eggs of $E$. scutalis and daily mean temperature was significantly positive for all stages, the amounts of L.S.D values were in Jan. 13.00 and 6.75. Population gradually increased to reach the peak of $E$. scutalis on Dec. with 
26.00 and 42.25 moving stages per nine leares. respectively; then the population gradually decreased to reach the lowest level in Jan. for both moving stages and eggs with averages of 9.50 and 15.5 per nine leaves, respectively.

Population densities of $T$. urticae and $E$. scutalis on S. podophyllum.

The populations gradually increased to reach the peak for T. urticae in Sept. with an average 37.00 eggs and 24.25 moving stages per nine leaves. respectively; then the population gradually decreased to reach the lowest level on Mar. ${ }^{1 \text { st }}$ for moving stages with averages of 8.50 and 12.75 per nine leaves, respectively The intercourse between the population of adults, moving stages of E. scutalis and daily mean temperature was significantly positive for all stages: the amounts of L.S.D values were on mid Aug. 16.00 and 19.25 ,then population gradually increased to reach the peak of E. scutalis on Dec. 26.00 eggs and 42.25moving stages per nine leaves then population gradually decreased to reach the lowest level in Mar. 9.25 eggs and 13.25 moving stages.

The Data showed that two factors had a strong effect on the abundance of mite on Spearmint plants. The statical analysis proved that the daily mean temperature positively affected the population of the arthropods associated with spearmint plants; while on the contrary; relative humidity had a negative effect. This agrees with Sheref et al. (1981) who reported that weather temperature significantly affected phy tophagous mite population. Abo Shnaf (2009) also reported that $T$. urficae density increased rapidly in July and remained at a high level until September; population then gradually decreased until February.

Finely. this study showed that in organic farming, the predator Euseius scutalis had a great effect in reducing $T$. urticae prey as negative correlations occurred. The increase of the predator under conditions of organic farming decreased associated pests specially $T$. urticue.

\section{REFERENCES}

Abo-Shnaf. R. I. A. 2009. Studies on some acarine and insect pests infesting ornamental, aromatic and medicinal plants. Ph. D. Thesis, Faculty of Agriculture. Cairo University, Egypt, 277 pp.

Shereef. G. M.: Hanna, M. A. and Megali, Magda K. 1981 b. Densities of important phytophagous and predaceous mites on verb scum. rose and peppermint. Bull. Soc. Ent. Egypte. 63:63-71.

Swirski, E; Amitai, S. and Dorzia, N. 1967. Laboratory studies on the feeding, development and oviposition of the predacious mite Amblyseius rubini Swirski and Amitai and Amblyseius swirski Athias-Henriot (Acari: Phytoseiidae) on various kinds of food substances. Israel J. Agric. Res., 17:101-119. 